\title{
STUDY ON THE CHARACTERISTICS AND BEHAVIOR OF EXPANSIVE SOILS
}

Paulo César Burgos a, Felipe Costa Albuquerquea; Luiza Santos Giron Margalhoa, Leonardo Machado Borges ${ }^{b}$, Marianna Luna Sousa Rivettia, Giulia Costa Ghirardia, Larissa da Silva Paes Cardoso

a SENAI CIMATEC, Brazil,

b VIABAHIA, Brazil

\begin{abstract}
The present study has the main objective of discussing about the characteristics and behavior of potentially expansive soils. These soils are present in several geographic regions across the world and exhibit variations in volume that consists of expansion or contraction, which are function of increasing or reducing its moisture content. A survey of the technical literature on the topic was carried out to support the study. The used methodology consisted of the application of direct and indirect methods that are based on index properties and in the conduct of laboratory tests. The obtained results were analyzed and compared to estimate the swelling potential and soil behavior. Therefore, the final considerations were presented.
\end{abstract}

Keywords: Expansive soils; vertisols; swelling potential.

\section{ESTUDO SOBRE AS CARACTERÍSTICAS E COMPORTAMENTO DE SOLOS EXPANSIVOS}

Resumo: O presente estudo tem como objetivo principal discutir sobre as características e comportamento de solos potencialmente expansivos. Esses solos estão presentes em diversas regiões geográficas do mundo e apresentam variações de volume que consistem em expansão ou contração, que são função de aumentar ou reduzir seu teor de umidade. Para subsidiar o estudo foi realizado um levantamento da literatura técnica sobre o tema. A metodologia utilizada consistiu na aplicação de métodos diretos e indiretos baseados em propriedades de índice e na realização de testes laboratoriais. Os resultados obtidos foram analisados e comparados para estimar o potencial de expansão e o comportamento do solo. Portanto, foram apresentadas as considerações finais.

\section{INTRODUCTION}

There are many studies on the behavior of swelling potential unsaturated soils have grown in recent years across the world and shows the complexity of the topic. This complexity includes several factors related to soil structure, mineralogy, and physical-chemical processes of laborious measurement, complemented by the interaction and influence of the climate. Several factors intervene in the expansion mechanism of clays that exhibit a very complex interaction system, with participation of the soil's intrinsic properties, state of tension and environmental factors. 
Swelling potential soils cause hard technical problems during the implementation and operation of construction and engineering works, specially on road pavements, embankments, and constructions with shallow foundations, due to their instability within moisture variation content, which becomes expansive in presence of withdrawing water.

According to [1], the distribution of expansive soils on the globe is linked to geological and climatic factors, being confined, mainly to semi-arid regions of tropical and temperate zones. Its abundance occurs where annual evapotranspiration exceeds precipitation. This is supported by the theory that in low or absent semi-arid regions, leaching helps the formation of expansive clay minerals.

Expansive soils cause damage on several highways around the world. In Brazil, there is an important sedimentary basin, the Recôncavo Baiano basin, which is made up of highly expansive soils, popularly called in Brazil as "massapê", and is referred in soil science as vertisol. The presence of expansive soils in road constructions and works is closely linked to deformations, causing various damages to the track and to the cut and embankment slopes, establishing a reduction in the level of comfort for the user and a significant increase in the need for maintenance, which demands greater investments. Worldwide, spending on this series of problems are usually in the amounts of billions of dollars. Therefore, understanding the factors that contribute to the phenomenon of expansiveness of these soils is of great importance to support the taking of remedial actions. There is also a need for the development of technologies that enable improvements in the maintenance of roads built above these soils.

Normally, the use of expansive soils in works of earth is avoided whenever is possible, due to the undesirable properties and behaviors that these soils show in the face of changes in the moisture content. However, in many field situations, there are regions with occurrences of swelling potential materials that initially require the technical staff to conduct a geotechnical investigation program with these materials, which aims to predict the behavior of these soils. It should be noted that the studies can take place in samples in the conditions of soils endowed with natural structures from their genesis, which indicates the use of undisturbed samples, as well as in samples from landfills, which represent structures in compacted conditions.

Several criteria for the identification and classification of swelling potential soils have been developed by several authors, and many of these procedures are related to the index properties of soils, which are routinely determined in traditional soil mechanics laboratories, as a consequence of easy applicability in the technical environment. Thus, this work aims to discuss about characteristics and behavior of potentially expansive soils.

\section{HISTORIC BACKGROUND}

The related literature reports that the problems associated with the behavior of swelling potential soils were only recognized after the year 1930 . Before, all the damages derived from the behavior of these soils in works had their problems attributed to construction errors or the manifestation of differential settlements. In view of the numerous pathologies existing with these expansive materials, studies were initiated related to swelling expansive clays, in order to understand the expansion mechanism of these soils, mainly by the absorption of infiltration water. It should be noted that the first conferences on this subject took place in Texas - USA, in the years 
1965 and 1969, followed by others around the world, including the tenth conference, which was held in Recife, Brazil, in the year 2002.

[2] comment that expansive soils have caused more damage to small work projects, particularly buildings and pavements, than any other natural risk, including earthquakes and floods. In Chine, the economic losses produced by the behavior of expansive soils have been estimated at approximately fifteen billion dollars a year, impacting around three hundred million people. In the United States of America, annual expenditure estimates for damages caused to installed structures expansive soils are in the order of seven billion dollars, equivalent to more than twice the costs associated with floods, hurricanes, tornadoes and earthquakes, according to [3]. In Brazil there are no records of values related to the theme, regarding economic losses, only research results about the properties and geotechnical behavior of these soils, mainly based on laboratory tests.

Currently, aiming at the stabilization of swelling potential soils, geotechnical engineering has mainly used mechanical and chemical stabilizations, which aim to provide the material with satisfactory behavioral geotechnical properties, in terms of mechanical resistance, deformability and permeability, since these soils do not exhibit favorable properties regarding their use in civil works. Mechanical stabilization adopts textural procedures for correcting the granulometric curve, while chemical stabilization refers to complex interactions based on chemical reactions, cation exchange, among others, with the most used additives for this purpose being lime and cement. Laboratory studies often reveal interesting results with these materials, however, when applying in the field, difficulties are encountered, mainly for mixing and homogenizing the additive to the soil, indicating the influence of the scale factor, laboratory versus field as a limiting agent for achieving the expected results. There is a need to develop new technologies applied to these soils for proper stabilization.

In areas of tropical climate occurrence, where the soils are mostly in the unsaturated state, several problems of geotechnical engineering are linked to water infiltration in the earth massif, in which the water may accrue from rains that come from nature or due to some anthropic activity, that is, of unnatural origin, which can promote the phenomena of expansion or collapse, this one being outside the scope of this study. The manifestation of expandability in works generally causes many pathologies that are revealed by the volumetric changes, requiring from the technical part specific studies for proper correction, as well as requiring additional costs, usually significant.

The development of projects and executive procedures in the construction stage of any type of work that presents expansive soils in its environment, requires the technical team knowledge about the behavior of these materials, because if these are not investigated and interpreted properly they can cause significant damage to buildings.

The technical literature indicates that a soil can be considered as swelling potential when it exhibits volumetric variation due to changes in its moisture content or suction and also presents a predominance of type 2:1 clay minerals and low hydraulic conductivity.

Some predominant characteristics are indicative of the occurrence of potentially expansive soils, and some qualitative indications are presented below according to [4]:

- Unsaturated soils;

- Soils with clay minerals of the type montmorillonite or vermiculite; 
- Contractions and expansions with the appearance of friction surfaces;

- Soils with low drainage and high activity, derived from igneous rocks, basically basalt, diabase and gabbro and sedimentary rocks basically shales, marl and limestone;

- Soils in regions where evapotranspiration exceeds precipitation, semi-arid regions with a tropical and temperate climate.

Environmental information inherent to the climate are relevant in the study of expansive soils - precipitation, temperature, air humidity and evaporation, which together with the characteristics of physical, chemical and mineralogical properties of the soils enable a better analysis and understanding of the behavior prediction. It is known to the technical environment that the partially saturated soils have their mechanical behavior modified by variations in their moisture content, revealing their considerable sensitivity to water. The active zone that corresponds to the stretch subject to volume variation, must be identified and monitored in the field and is of extremely importance for the studies of expansive soils. The volume variation results from any changes in the moisture content. Usually, the identification of this zone is based on field monitoring, understanding at least one of the following: the relationship between the water content, or suction or vertical displacement along the depth. Figures 1 and 2 show typical examples of an active zone, according to [5]:

Figure 1. Water content versus depth

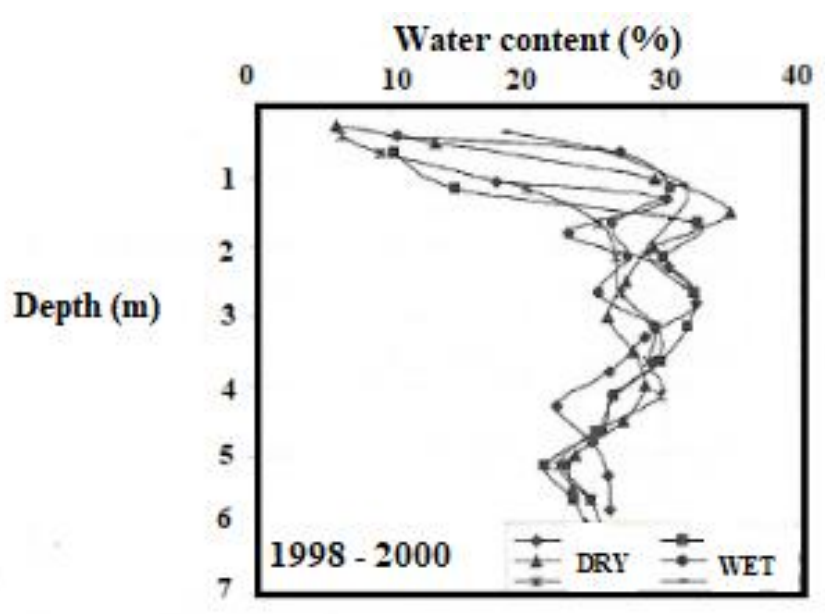

Source: [5] 
Figure 2. Matric suction and vertical displacement versus depth

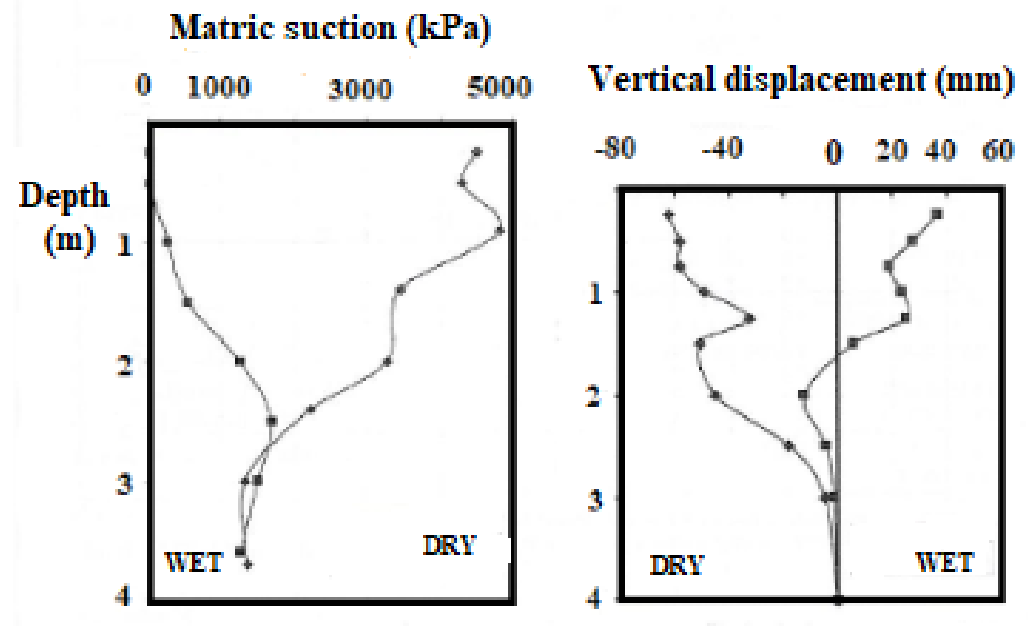

Source: [5]

\section{METODOLOGY}

In order to identify the soil swelling potential through the application of some criteria that make use of parameters commonly determined in the Soil Mechanics laboratories, some indirect methods and the direct methods that are usually employed for this purpose are presented.

\subsection{Indirect Methods}

These methods are divided into identifying, qualitative and guiding criteria. They are based on mineralogy, granulometry, consistency limits, index properties and geopedological characteristics. Figure 3 corresponding the organization chart:

Figure 3. Indirect Methods

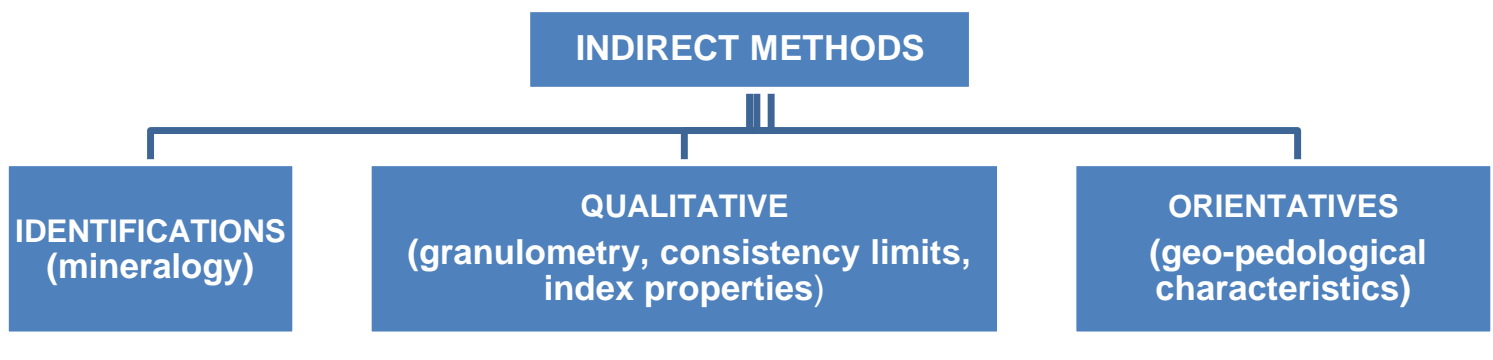

Source: Authors (2020).

The indirect qualitative methods of identifying the expansive character of a soil, have been used in the technical environment as a preliminary alternative to assess the predisposition to expansiveness. Indirect identification methods are currently less used, due to high cost issues. Meanwhile, indirect guidance methods require knowledge of the geo-pedological area, not common to civil engineering. Many researchers have developed studies aimed at the preliminary identification of expansive behavior based on the results of tests of complete characterization of the soil, tests that are frequently carried out in laboratories.

The complete characterization includes the granulometry tests by sieving and sedimentation, liquidity limit, plasticity limit and specific weight of the solids. This test 
cast aims to gather soils of similar aptitudes and properties in the same group for the initial prediction of their behavior in the various applications of engineering works.

Dealing with some indirect qualitative methods, we initially present the activity (A) proposed by [6], which measures the influence of mineral clay on soil properties and is based on clay content and plasticity index. This criterion indicates three degrees of activity, clay inactive $(A<0.75)$; normal clay $(0.75<A<1.25)$ and active clay $(A>1.25)$. Another similar criterion is illustrated in Figure 4 with the Van der Merwe Chart [7] that relates the clay percentage to the plasticity index, indicating four hierarchical areas of expansion potential based on the mineralogical activity of the soil:

Figure 4. Van der Merwe Chart

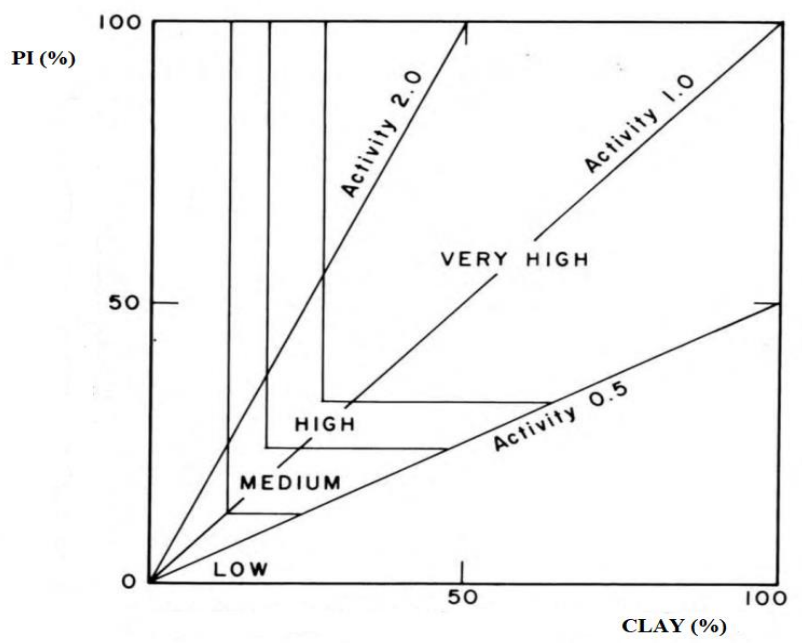

Source: [7].

Table 1 shows classifications of expansive soils based on the liquid limit (LL) and plasticity index (PI) properties, according to some criteria proposed by several authors:

Table 1. Classification of the degree of expansion according to the liquid limit values and the plasticity index, expressed in percentages

\begin{tabular}{|c|c|c|c|}
\hline $\begin{array}{c}\text { SWELLING } \\
\text { POTENTIAL }\end{array}$ & Seed et. al. (1962) & Chen (1965) & $\begin{array}{c}\text { Daksanamurthy e } \\
\text { Raman (1973) }\end{array}$ \\
\hline Very High & $\mathrm{PI}>35$ & $\mathrm{LL}>60$ & $\mathrm{LL}>70$ \\
\hline High & $20<\mathrm{PI} \leq 35$ & $40<\mathrm{LL} \leq 60$ & $50<\mathrm{LL} \leq 70$ \\
\hline Medium & $10 \leq \mathrm{PI} \leq 20$ & $30 \leq \mathrm{LL} \leq 40$ & $35<\mathrm{LL} \leq 50$ \\
\hline Low & $\mathrm{PI}<10$ & $\mathrm{LL}<30$ & $20 \leq \mathrm{LL} \leq 35$ \\
\hline
\end{tabular}

Source: $[8,9,10]$.

\subsection{Direct Methods}

These methods consist of laboratory tests using an edometric cell. They are called free expansion test, expansion voltage test and expansion test with controlled overload. It is noted that at a global level there is no standardization of technical 
procedures for the execution of these tests regarding the expansion stress test, the determination is quite complex and governed by the stress path induced in the test.

\section{RESULTS ANALYSIS AND DISCUSSION}

For the purposes of practical application of qualitative indirect methods, we present a numerical example for a vertisol (massapê) from the Ilhas Formation, a soil that occurs in areas of the Metropolitan Region of Salvador - BA. Table 2 present a summary of some properties of this soil, comprising granulometric and consistency information, complemented by the specific weight of the solids and the geotechnical classifications by the USCS and TRB Systems, respectively:

Table 2. Summary of the results of the full characterization tests

\begin{tabular}{|c|c|c|c|c|c|c|c|c|}
\hline Sand (\%) & Silt (\%) & Clay (\%) & LL (\%) & PL (\%) & PI (\%) & $\gamma_{\mathbf{s}}\left(\mathbf{k N} / \mathbf{m}^{3}\right)$ & USCS & TRB \\
\hline 10 & 26 & 64 & 89 & 36 & 53 & 26,9 & CH & A-7-5(20) \\
\hline
\end{tabular}

Source: Authors (2020).

Figures 5 and 6 show the granulometric curve and the positioning of the soil in the Plasticity Chart:

Figure 5. Granulometric curve

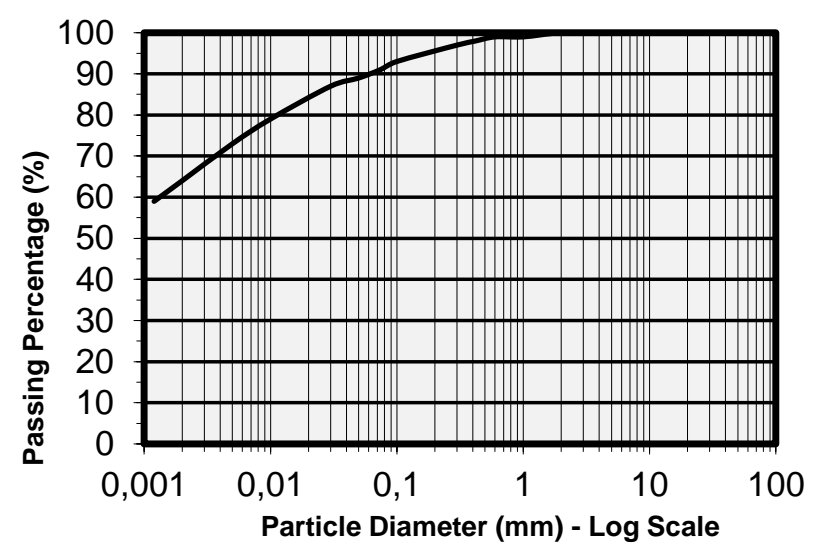

Source: Authors (2020).

Figure 6. Plasticity chart

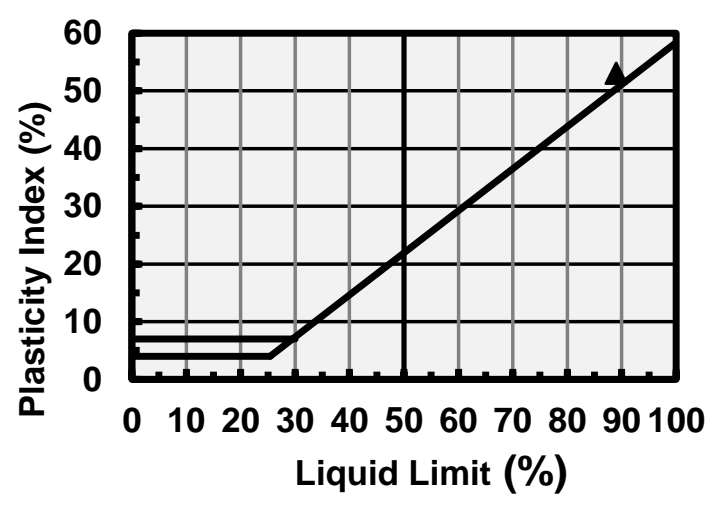


Source: Authors (2020).

The soil was classified as inorganic clay of high compressibility $(\mathrm{CH})$ by the USCS System and in the TRB System it was classified in the group A-7-5 (20) that represents predominantly clay soils. In terms of mineralogical activity according to the proposal of [6], the soil was classified as normal activity, showing the value of the activity index characteristic of illite. For [7] the swelling potential obtained was very high.

The prediction swelling potential of the soil by the qualitative indirect methods of $[8,9,10]$ indicated a very high degree of expansion.

\section{FINAL CONSIDERATIONS}

As it is a soil known to be expansive, it can be observed that the qualitative indirect methods used in this study were effective for the preliminary estimate of the swelling potential, with significant agreement between them.

\section{Acknowledgments}

We thank SENAI CIMATEC and VIABAHIA for their financial support through the EMBRAPII Resources Program.

\section{REFERENCES}

${ }^{1}$ CHEN, F.H. Foundation on Expansive Soil. Elsevier, Amsterdam, 275 p., 1975.

2 JONES, D.E. e HOLTZ, W.G. Expansive Solis - the hidden disaster. Civil Eng., ASCE, 43 (8), p. 4951, 1973.

${ }^{3}$ RAMA RAO, R., RAHARDJO, H. and FREDLUND, D.G. Closed-Form Heave Solutions for Expansive Soils, Journal ASCE, 1988.

${ }^{4}$ VILAR, O.M. e FERREIRA, S.R.M. Solos não saturados no contexto geotécnico. São Paulo: Associação Brasileira de Mecânica dos Solos e Engenharia Geotécnica, 759 p., 2015.

5 JUSTINO DA SILVA, J. M. Geotecnia no Nordeste. Recife: UFPE, 543 p.,2005.

${ }^{6}$ SKEMPTON, A. W. The Colloidal Activity of Clays. Proceedings of $3^{\text {rd }}$ International Conference on Soil Mechanics and Foundation Engineering, Zurich, v. 1, p. 57-61, 1953.

${ }^{7}$ VAN DER MERWE, D. H. The Predication of Heave from the Plasticity Index and the Percentage Clay Fraction. The Civil Engineering in South Africa, v. 6, p. 103-107, 1964.

8 SEED, H.B., WOODWARD, R.J. and LUDGRAN, R. Prediction of Swelling Potential of Compacted Clays. Journal of Soil Mechanics and Foundation Division, ASCE, 88(SM3): 53-87, 1962.

${ }^{9} \mathrm{CHEN}$, F.H. The use of piers to prevent the uplifiting of the lightly loaded structures founded on expansive clays. $\mathbf{1}^{\text {st }} \mathbf{3}^{\text {rd }}$ International Conference on Expansive Solis, Texas, pp. 152-171, 1965.

10 DAKSANAMURTHY, V. e RAMAN, V. A simple method of identifying an expansive soil. Soils and Foundation, Japanese Society of Soil Mechanics and Foundation Engineering, 13(1): pp.97-104, 1973. 